\title{
Hubungan antara Status Nutrisi dan Penggunaan Alat Bantu Nafas pada Pasien di ICU
}

\author{
Hellena Deli ${ }^{1}$, T. Abdur Rasyid ${ }^{2}$, Muhammad Refki $^{3}$ \\ ${ }^{1,2}$ Staff Dosen Keperawatan Gawat Darurat dan Kritis STIKes Hangtuah Pekanbaru, \\ ${ }^{3}$ Mahasiswa PSIK STIKes Hang Tuah Pekanbaru \\ Email: hellenadeli.hd@gmail.com, tengkuabdurrasyid@gmail.com
}

Disetujui: 27 September 2018

\begin{abstract}
Abstrak
Latar belakang: Status nutrisi dapat mempengaruhi fungsi paru. Malnutrisi dapat menimbulkan kegagalan pada fungsi pernapasan. Nutrisi merupakan salah satu prediktor dalam manajemen masalah pernapasan, sehingga dibutuhkan pemantauan terhadap status nutrisi.

Tujuan: Penelitian ini bertujuan untuk mengetahui hubungan antara status nutrisi dengan penggunaan alat bantu pernapasan pada pasien di intensive care unit (ICU).

Metode: Desain yang digunakan pada penelitian ini adalah observasional analitik dengan pendekatan cohort study. Penelitian ini dilakukan pada 22 orang responden yang dirawat di ICU RSUD Arifin Achmad Pekanbaru. Analisa data yang digunakan pada penelitian ini adalah analisa univariat dan bivariat. Uji statistik yang digunakan pada penelitian ini adalah chi square untuk melihat hubungan antara status nutrisi dengan penggunaan alat bantu pernapasan pada pasien di ICU.

Hasil: Berdasarkan hasil penelitian ini didapatkan mayoritas responden berjenis kelamin laki-laki sebanyak 13 orang $(59.1 \%)$, mayoritas responden berada pada usia lansia ( $\geq 60$ tahun) sebanyak 10 orang (45,5\%), dengan mayoritas diagnosis medis adalah stroke sebanyak 10 orang $(45,5 \%)$, mayoritas responden mengalami malnutrisi sebanyak 14 orang $(63,4 \%)$, dan mayoritas responden tidak menggunakan ventilator sebanyak 12 orang (54,5\%). Hasil analisis Chi square didapatkan bahwa terdapat hubungan antara status nutrisi dengan penggunaan alat bantu pernapasan pada pasien di ICU dengan $\rho$ value 0,02 ( $\rho$ value $<0,05$ ).

Simpulan:Status nutrisi memiliki hubungan yang signifikan terhadap penggunaan ventilator pada pasien yang dirawat di ICU RSUD Arifin Achmad Pekanbaru.
\end{abstract}

Kata kunci: Gagal nafas, intensive care unit, malnutrisi, status nutrisi, ventilator

Rujukan artikel penelitian:

Deli, H., Rasyid, A., Refki, M. (2018). Hubungan antara Status Nutrisi dan Penggunaan Alat Bantu Nafas pada Pasien di ICU. Jurnal Ilmiah Keperawatan Indonesia. Vol. 2 (1): 1 - 9. 


\begin{abstract}
Background: Nutritional Status can affect the lung function. Malnutrition can lead to failure of respiratory function. Nutrition is one of the predictors in the management of respiratory problems, so that required monitoring of nutritional status.

Objective: This study purposed to find out the relationship between nutritional status with use of respiratory supporting device in patient in intensive care unit (ICU).

Methodology: this study used observational analytic design with cohort study approach. This study was conducted on 22 respondents who hospitalized in the ICU of RSUD Arifin Achmad Pekanbaru. Analysis of the data used univariate and bivariate analysis. The statistical analysis of this study was chi square test to determine the relationship between nutritional status with use of respiratory supporting device.

Results: The results of this study obtained a majority of the respondents were male-sex as many as 13 people (59.1\%), the majority of respondents were elderly ( $\geq 60$ years) with total of 10 people $(45.5 \%)$, the majority of the medical diagnosis of respondents were stroke as many as $10(45.5 \%)$, a majority of respondents experienced malnutrition as many as 14 people (63.4\%), and the majority of respondents did not use respiratory supporting device as many as 12 people (54.5\%). Chi square analysis results obtained that there was a relationship between the nutritional status with the use of the respiratory supporting device on patients in the ICU with $\rho$ value of 0.02 ( $\rho$ value $<0.05$ ).

Conclusion: Nutritional status has a significant relationship to the use of respiratory supporting device in ICU patients at RSUD Arifin Achmad Pekanbaru.
\end{abstract}

Keywords: Intensive care unit, nutritional status, malnutrition, respiratory failure, respiratory supporting device.

\title{
PENDAHULUAN
}

Nutrisi merupakan salah satu komponen penting yang harus diperhatikan dalam perawatan pada pasien kritis. Pasien yang dirawat di intensive care unit (ICU) pada dasarnya memiliki penyakit berbeda yang sangat membutuhkan nutrisi sebagai pendukung penyembuhan. Faktor yang dapat mempengaruhi perubahan status nutrisi salah satunya adalah disebabkan oleh peningkatan katabolisme yang terjadi sebagai akibat dari respon penyakit yang dialami (Eskandar \& Apostolakos, 2007; Boles et al, 2007; Martin, Smith, \& Gabrielli, 2013).

Malnutrisi yang terjadi pada pasien ICU merupakan salah satu hal yang dapat meningkatkan morbiditas dan mortalitas. Malnutrisi dapat memberikan 
kontribusi yang sangat buruk bagi kesembuhan pasien bahkan dapat menyebabkan kematian. Hal ini disebabkan oleh pengurangan masa tubuh yang dapat berakibat kepada penurunan fungsi pernapasan, menginduksi kelelahan otot dan dapat mengakibatkan gagal nafas akut. Malnutrisi dapat mengurangi kekuatan masa otot sekitar $37 \%$, $41 \%$ maximal voluntary ventilation, penurunan kapasitas vital paru sebesar 63\% (Arora \& Rocheste, 1982; Keens, Bryan, Levison \& Lanuzzo, 1978).

Malnutrisi dapat mengakibatkan hipofosfatemia, hipomagnesemia, hipokalsemia dan hipokalemia yang dapat menyebabkan kelemahan pada otot pernapasan. Hal ini dapat mengakibatkan terjadinya kegagalan pernapasan serta menghambat proses weaning ventilator. Kekurangan kalori dan protein tubuh juga dapat mengakibatkan penurunanan masa otot diagfragma, hal ini mengakibatkan pemberian kalori tambahan harus dilakukan. Namun pemberian kalori yang berlebihan pun harus dihindari karena dapat meningkatkan ventilasi. Pemberian diit pada pasien dengan ventilator adalah diit tinggi protein rendah karbohidrat, hal ini karena proses pemecahan karbohidrat menghasilkan $\mathrm{CO}_{2}$ yang besar yang pada akhirnya dapat meningkatkan beban kerja ventilasi. Pencernaan lemak dan protein lebih sedikit menghasilkan $\mathrm{CO}_{2}$, sehingga tidak meningkatkan ventilasi (Eskandar \& Apostolakos, 2007; Martin et al, 2013).

Protein dan albumin dapat membantu mengevaluasi status nutrisi. Status nutrisi pasien merupakan hal yang sangat kompleks dan harus sepenuhnya dievaluasi. Protein dan albumin diperlukan untuk membangun dan memperbaharui kembali sel-sel otot, termasuk otot pernapasan. Pasien dengan status nutrisi kurang baik mungkin dapat dilakukan weaning ventilator dengan cepat, namun mereka tidak memiliki daya tahan, sehingga sangat besar kemungkinan dilakukan reintubasi sebelum 24 jam (Eskandar \& Apostolakos, 2007; Martin, 2009).

\section{BAHAN DAN METODE}

Penelitian ini merupakan penelitian observasi analitik dengan pendekatan cohort study. Instrument yang digunakan pada penelitian ini adalah lembar observasi, dimana untuk melihat status nutrisi menggunakan modifikasi lembar 
observasi berdasarkan pengukuran Stewart. Adapun indikator yang dinilai adalah BMI, Kadar serum albumin, dan Penurunan berat badan yang tidak disengaja. Penelitian ini dilaksanakan diruangan ICU RSUD Arifin Achmad Pekanbaru. Sampel pada penelitian ini sebanyak 22 orang. Teknik pengambilan sampel dilakukan secara konsekutif. Penelitian ini memiliki kriteria inklusi meliputi: semua pasien yang baru pertama kali dirawat di ICU dan bersedia menjadi responden. Kriteria ekslusi adalah keluarga yang tidak mengetahui penurunan berat badan responden dalam 3 bulan terakhir. Analisis data yang digunakan pada penelitian ini adalah analisa univariat dan bivariat. Analisis univariat digunakan untuk menggambarkan karakteristik responden, sedangkan analisis bivariat digunakan untuk melihat hubungan status nutrisi dengan penggunaan ventilator di ICU RSUD Arifin Achmad. Uji statistik yang digunakan adalah uji chi square.

\section{HASIL}

1. Karakteristik Responden

Hasil penelitian didapatkan mayoritas responden yang dirawat di ICU RSUD Arifin Achmad berjenis kelamin laki-laki sebanyak 13 orang (59.1\%), mayoritas responden berada pada rentang usia lansia sebanyak 10 orang (45,5\%), dengan mayoritas responden didiagnosis stroke sebanyak 10 orang (45,5\%), mayoritas responden mengalami malnutrisi sebanyak 14 orang $(63,4 \%)$, dan mayoritas responden tidak terventilator sebanyak 12 orang $(54,5 \%)$ (Tabel 1). 
Tabel 1. Distribusi Responden Berdasarkan Jenis Kelamin, Usia, Jenis Penyakit, Penggunaan Alat Bantu Nafas, Status Nutrisi N= 22

\begin{tabular}{llll}
\hline No & Karakteristik & $\mathrm{n}$ & $\%$ \\
\hline 1 & Jenis Kelamin & & \\
& Laki-Laki & 13 & 59,1 \\
& Perempuan & 9 & 41,9 \\
& Usia & & \\
& Remaja Akhir & 1 & 4,5 \\
& Dewasa awal & 3 & 13,6 \\
& Dewasa Akhir & 8 & 36,4 \\
& Lansia & 10 & 45,5 \\
3 & Jenis Penyakit & & \\
& Cedera kepala berat & 5 & 22,7 \\
& Cedera kepala sedang & 1 & 4,5 \\
& Stroke & 10 & 45,5 \\
& Hemothoraks & 1 & 4,5 \\
& Post Craniotomi & 5 & 22,7 \\
4 & Status Nutrisi & & \\
& Malnutrisi & 14 & 63,6 \\
& Tidak Malnutrisi & 8 & 36,4 \\
5 & Penggunaan Alat Bantu Nafas & & \\
& Menggunakan ventilator & 10 & 45,5 \\
& Tidak menggunakan ventilator & 12 & 54,5 \\
\hline$\quad$ Total & 22 & 100 \\
\hline
\end{tabular}

2. Hubungan status nutrisi terhadap penggunaan alat bantu nafas pada pasien di ICU RSUD Arifin Achmad Provinsi Riau

3.

Tabel 2. Hubungan status nutrisi terhadap penggunaan alat bantu nafas pada pasien di ICU RSUD Arifin Achmad Provinsi Riau N= 22

\begin{tabular}{lcccc}
\hline Status Nutrisi & \multicolumn{2}{c}{ Penggunaan alat bantu nafas } & Total & P Value \\
\cline { 2 - 4 } & $\begin{array}{c}\text { Menggunakan } \\
\text { ventilator }\end{array}$ & $\begin{array}{c}\text { Tidak } \\
\text { menggunakan } \\
\text { ventilator }\end{array}$ & & \\
\hline Malnutrisi & 10 & 4 & 14 & 0,02 \\
\hline Tidak Malnutrisi & 0 & 8 & 8 & \\
\hline Jumlah & 10 & 12 & 22 & \\
\hline
\end{tabular}


Berdasarkan tabel 2 didapatkan hasil analisis chi square, nilai $\rho$ value 0,02 ( $\rho$ value $<0,05$ ). Hal ini menunjukkan bahwa terdapat hubungan antara status nutrisi dengan penggunaan ventilator.

\section{PEMBAHASAN}

Status nutrisi merupakan suatu komponen penting pada perawatan pasien kritis dan memiliki pengaruh yang besar dalam proses penyembuhan pasien. Perubahan status nutrisi pada pasien kritis disebabkan oleh peningkatan proses katabolisme yang muncul akibat dari respon penyakit yang didertia pasien. Selain itu, penggunaan naso gastric tube (NGT) juga dapat mengakibatkan terbatasnya asupan nutrisi. Kondisi demam yang dialami pasien sebagai akibat dari peningkatan metabolisme dapat mengakibatkan meningkatnya jumlah kalori yang dibakar tubuh, selain itu gangguan pada gastro intestinal juga dapat mengurangi asupan maupun penyerapan nutrisi terganggu, sehingga mengakibatkan terjadinya malnutrisi (Eskandar \& Apostolakos, 2007; Boles et al, 2007; Martin, Smith, \& Gabrielli, 2013). Malnutrisi dapat memberikan out come yang buruk bagi pasien kritis, pasien dengan status kecukupan gizi rendah secara signifikan memiliki kelangsungan hidup yang lebih pendek dibandingkan pasien dengan status kecukupan gizi baik (Wey, Day, Ouellette-Kuntz, \& Heyland, 2015).

Berdasarkan penelitian yang dilakukan oleh O'Leary-Kelley et al (2005) mayoritas responden yang dirawat diruangan intensif mendapatkan asupan nutrisi yang rendah, sekitar 38\% responden mendapatkan nutrisi kurang dari 50\% kebutuhan energi pasien. Hasil dari penelitian ini didapatkan bahwa dari 14 pasien yang mengalami malnutrisi didapatkan 10 orang yang menggunakan ventilator. Hal ini sesuai dengan penelitian yang dilakukan oleh Wei, Day, Ouellette-Kuntz \& Heyland (2015) terhadap 1223 pasien yang dirawat diruangan ICU yang memenuhi kriteria, didapatkan 475 orang pasien terpasang ventilator dengan status nutrisi rendah, sedang dan tinggi. Hasil penelitiannya juga menunjukkan pasien yang memiliki status nutrisi rendah lebih lama terpasang ventilator dibandingkan pasien dengan status nutrisi tinggi. Menurut Kacmarek, Stoller, \& Heuer (2016), status malnutrisi dapat mengakibatkan berkurangnya masa dan 
kontraktilitas otot diagfragma dan otot bantu pernapasan. Selain itu juga mengakibatkan batuk menjadi tidak efektif, penurunan tekanan inspirasi dan ekspirasi maksimum, berkurangnya produksi surfaktan, peningkatan produksi $\mathrm{CO} 2$, penurunan kemampuan pembersihan paru, dan peningkatan kolonisasi bakteri. Sehingga malnutrisi dapat mengakibatkan terjadinya peningkatan risiko penggunaan ventilator dibandingkan pasien dengan status nutrisi yang baik.

Berdasarkan hasil penelitian yang dilakukan oleh Faisy et al (2009) pada pasien yang terpasang ventilasi mekanik lebih dari 7 hari mengalami defisit energi sekitar 1200kkal/hari yang secara tidak langsung berkaitan dengan peningkatan angka kematian pasien di ICU. Oleh karena itu, dibutuhkan suatu pemantauan dan pengkajian bagi pasien yang memiliki risiko tinggi mengalami malnutrisi yang dapat meningkatkan potensi penggunaaan ventilasi mekanik dan meningkatkan risiko penggunaan ventilasi mekanik dalam jangka waktu yang lama.

Gangguan metabolik yang ditimbulkan pada pasien dengan malnutrisi adalah terjadinya hiperglikemia, peningkatan kadar laktat, hipertrigliseridemia dan konsentrasi nonesterified fatty acis (NEFA) yang terjadi sebagai akibat dari retensi insulin yang ditandai dengan terjadinya hipermetabolik pada pasien kritis. Perubahan komposisi tubuh dapat memperburuk outcome pasien. Pemberian nutrisi enteral pada 24-48 jam pertama dirawat menunjukkan terjadinya penurunan permeabilitas usus dan pelepasan sitokin dibandingkan pada pasien yang mendapatkan nutrisi enteral setelah 72 jam dirawat. Pemberian nutrisi diawal dapat meningkatkan motilitas usus, dan menurunkan intoleransi lambung (Doig, Heighes, Simpson, Sweetman, \& Davies, 2009). Dalam pemantauan status nutrisi pasien perawat memiliki peranan yang penting. Perawat dituntut untuk mampu melakukan pemantauan, pemberian serta pengontrolan pemberian nutrisi sehingga dapat meningkatkan atau mempertahankan status nutrisi pasien.

\section{SIMPULAN DAN SARAN}

Hasil penelitian ini didapatkan mayoritas responden berjenis kelamin lakilaki, mayoritas responden adalah usia lanjut serta didiagnosis stroke. Selain itu, hasil penelitian ini juga didapatkan mayoritas responden malnutrisi dan mayoritas 
responden tidak menggunakan ventilator. Hasil penelitian ini menunjukkan bahwa terdapat hubungan antara status nutrisi dengan penggunaan ventilator pada pasien yang dirawat di ICU RSUD Arifin Achmad Provinsi Riau dengan nilai $\rho$ value 0,02 ( $\rho$ value $<0,05$ ). Hasil dari penelitian ini dapat dijadikan data dasar untuk penelitian selanjutnya mengenai pengukuran status nutrisi pada pasien dengan kondisi kritis dan dengan jumlah responden serta yang lebih banyak. 


\section{RUJUKAN}

Arora, N.S., Rochester, D.F. (1982). Respiratory muscle strength and maximal voluntary ventilation in undernourished patients. Am Rev Resp Dis;126:5-8. 2.

Boles, J. M., Bion, J., Connors, A., Herridge, M., Marsh, B., Melot, C., ... \& Welte, T. (2007). Weaning from mechanical ventilation. European Respiratory Journal, 29(5), 1033-1056.

Doig, G.S., Heighes, P.T., Simpson, F., Sweetman, E.A., Davies, A.R. (2009). Early enteral nutrition, provided within $24 \mathrm{~h}$ of injury or intensive care unit admission, significantly reduces mortality in critically ill patients: A metaanalysis of randomized controlled trials. Intensive Care Med, 35:20182027.

Eskandar, N., \& Apostolakos, M. J. (2007). Weaning from mechanical ventilation. Critical care clinics, 23(2), 263-274.

Faisy, C., Lerolle, N., Dachraoui, F., Savard, J. F., Abboud, I., Tadie, J. M., \& Fagon, J. Y. (2009). Impact of energy deficit calculated by a predictive method on outcome in medical patients requiring prolonged acute mechanical ventilation. British journal of nutrition, 101(07), 1079-1087.

Kacmarek, R. M., Stoller, J. K., \& Heuer, A. (2016). Egan's fundamentals of respiratory care. Elsevier Health Sciences.

Keens, T.G., Bryan, A.C., Levison, H., Ianuzzo, C.D. (1978). Developmental pattern of muscle fiber types in human ventilatory muscles. $J$ Appl Physiol ;44:909-13.

Martin, A.D., Smith, B.K., \& Gabrielli, A. (2013). Mechanical Ventilation, diagfragm weakness and weaning: a rehabilitation perspective. Respiratory physiology \&neurobiology, 189(2),337-383.

Martin, K.T. (2009). Weaning From Mechanical Ventilation. RC Educational Consulting Services, Inc.

O’Leary-Kelley, C. M., Puntillo, K. A., Barr, J., Stotts, N., \& Douglas, M. K. (2005). Nutritional adequacy in patients receiving mechanical ventilation who are fed enterally. American Journal of Critical Care, 14(3), 222-231.

Wei, X., Day, A. G., Ouellette-Kuntz, H., \& Heyland, D. K. (2015). The association between nutritional adequacy and long-term outcomes in critically ill patients requiring prolonged mechanical ventilation: a multicenter cohort study. Critical care medicine, 43(8), 1569-1579. 